\title{
The Emotional World of the Musical Work, Reflected in an Educational Video Clip
}

\author{
Krasimira Georgieva Fileva-Ruseva \\ Department of Piano and Accordion, Faculty of Musical Education, Academy of Music, Dance and Fine Arts, Plovdiv, Bulgaria
}

Email address:

krassyfilleva@abv.bg

\section{To cite this article:}

Krasimira Georgieva Fileva-Ruseva. The Emotional World of the Musical Work, Reflected in an Educational Video Clip. International Journal of Literature and Arts. Special Issue: Musical Theory, Psychology, Pedagogy and Performing. Vol. 3, No. 5-1, 2015 , pp. 62-71. doi: 10.11648/j.ijla.s.2015030501.19

\begin{abstract}
In order to prove that a computer-generated video clip could recreate in full value the emotional content of a musical piece, I presented the work on the creation of scenarios for video clips, based on the Bulgarian folk song "Izgreyalo Yasno Slantze" ("A Bright Sun has Risen") and on Bagatelle №1 from the cycle "24 Bagatelles for Piano" by Ivan Spasov. The piano piece and the folk song are contrasting in terms of their character; the piano piece is created on the basis of dodecaphony, while the sound system of the folk song is the eolian mode with a subbase tone; the piano piece is by an author, as opposed to the folk song.
\end{abstract}

Keywords: Folk Song, Piano Piece, Video Clip, National Psychology, Ivan Spasov, Scenario

\section{Introduction}

Music is an art, whose language of expression not always happens to be accessible for the unprepared listener. In history, multiple cases have been known, when new methods used lead to the works ending up as misunderstood and rejected even by professionalists. One of the main things, which have to be perceived, when listening to a musical piece, as well as an essential element of understanding the work, is its emotional content. Without insight into the character of the work, its main purpose - to affect the feelings, the emotional world of the listener, cannot be achieved, and, without emotional impact, understanding the moral message of the work cannot be obtained.

Since in their interaction with the surrounding world, one depends significantly more on visual information, than on that, received through the other senses, vision acquires a higher sensory culture. In that case, it is natural for the perception of artistic products of complex arts, such as music, which is achieved through hearing, to be supported in a visual way.

The idea of reliance on visual information when perceiving works of the tone art is not new. Many attempts have been made to use pictures for that purpose. The picture, however, is a static image, which, fixating a certain event or state, cannot show changes in the character, such that are typical for musical works. Even if, while listening to the piece, the perceiver is shown a series of pre-selected pictures, they cannot reflect gradual changes, and some fine emotional nuances will be left unregistered.

In a feature film, shooting is limited by the capabilities of recreation, imposed by the conditions of reality. The artistic fantasy of the composer, however, is unbounded. In the 20th century, new forms of aesthetic practice have been created, such as the computer animation. Since, on the computer, any kind of image with any kind of actions and in any kind of conditions can be reproduced, even such, which do not exist in reality, if there is possibility that they exist in the fantasy world of the composer, there is no problem for them to be reproduced in an animation movie. For these reasons, I believe that the computer-generated video story has the capabilities of representing most completely and accurately the emotional world of the musical piece.

\section{Subject, Goals and Tasks of the Study}

The goal of the present study is the preparation of scenarios for computer-generated video clips with a faithfully reproduced emotional content of the musical works, based on which the video stories are created. 
The subject of the study are musical works, provisioned for listening in the secondary general school and in professional education in piano.

The object of analysis is the emotional content of these works.

The specific tasks are:

1. Analysis of the works, to which the scenarios for the video clips will be prepared.

2. Gathering and summarizing of information for the circumstances, related to the reviewed works.

3. Research and summarization of data about the personal characteristics of the authors of the works.

In order to prove that a video film, created with the means of computer animation, could reproduce faithfully the emotional contents of a musical work, I selected for research two works, clearly contrasting in character between each other; one of them is by an author, the other is folklore; one instrumental, the other - vocal; one uses dodecaphony for the organization of the tone texture, the other has the eolian mode for a sound system. These are Bagatelle №1 from the cycle "24 Bagatelles for Piano" by the Bulgarian composer Ivan Spasov, and the Bulgarian folk song "A Bright Sun has Risen".

\section{Preparation of the scenarios for the Video Clips}

\subsection{Preceding Activities}

Preparing the scenario for a video story to the specific work, the developer establishes the character and the changes in it, according to those of the musical work. In this way, the sharp contrasts and fine emotional nuances are present and their intensity is regulated, in complete synchrony with the changes in the character of the music.

The decision for the specific storyline is taken after gathering, researching and summarizing information of the characteristic features of the artistic signature of the composer, the specifics of the artistic period, in which the work has been created, the situation, accompanying the birth of the musical opus, the specific images, which possibly interested and inspired the author in that period, specific psychological characteristics of the personality of the tone author. All this data is considered and applied to the instructions, which the composer has left in the specific work - the presence of program title, of literary text (for vocal works), specifications for the tempo and character, genre specification, as well as the musical form of the work. In such a method, it is expected for the characters in the video, if not typical for the artistic fantasy of the author, to at least not be in contradiction with it.

The analyses, which I have made for the specific works, are presented below. I rely also on earlier prepared by me analyses - of the personal characteristics of the composer Ivan Spasov [6], of the content analysis of his two autobiographical books [4], as well as on literature on the questions of national Bulgarian psychology [8].

\subsection{Analysis and Information, Related to the Bulgarian Folk Song "A Bright Sun has Risen"}

\subsubsection{The Psychological Qualities of the Bulgarian People, which have a Relation to the Character of the Song "A Bright Sun has Risen"}

In order to derive these psychological characteristics of the people - author, which have a relation to the specific folk song, we have to seek out the characteristic features not of the contemporary Bulgarian people, living in new conditions, but of those, who have created the song, and the ritual, in which it was performed.

Among these characteristic features [8] is the strong bond of the Bulgarians with the land, which feeds them. They look upon the land by far not only as a means of survival and social prestige, but also as their mother, who nourishes them with her generosity, punishes them even for the smallest negligence, but also they take care of her, devote to her their strength, labor, creativity, time, hopes of prosperity. In the care for the land, the Bulgarians do not know rest, in their work, in the process of labor itself, and not even so much in the result of that labor, they find happiness. They create upon the land, protect it, when needed, even with their life; for it, despite their gentle and peaceful nature, they can lead battles, as well. The fertility of the land, its beautiful nature and the location of Bulgaria, on the road between Western Europe and the Orient, has made our country the object of many attempts of conquest by different people. Yet, no tribal Bulgarian battle flag has ever been captured. In this way, the care and attachment to the land leads to self-sacrifice. With the same care and devotion, the Bulgarians treat also their homes.

Their aesthetic sense is expressed in their attitude towards their home, their garden, the clothes they wear, the household objects, which they use every day, but which are "sparkling clean" and festively adorned. The beautiful does not even always have a relation with the functional. In the lives of Bulgarians, there are finely crafted items, which have no special everyday purpose, but a lot of work has been put in their creation and embedded in them is the desire to make life not only comfortable, but also beautiful. An evidence of all this are the carefully and astonishingly embroidered national costumes with beautiful color combinations (Figure №1 a, b, c), the presence of special clothes for the different traditions, the masterfully crafted everyday objects.

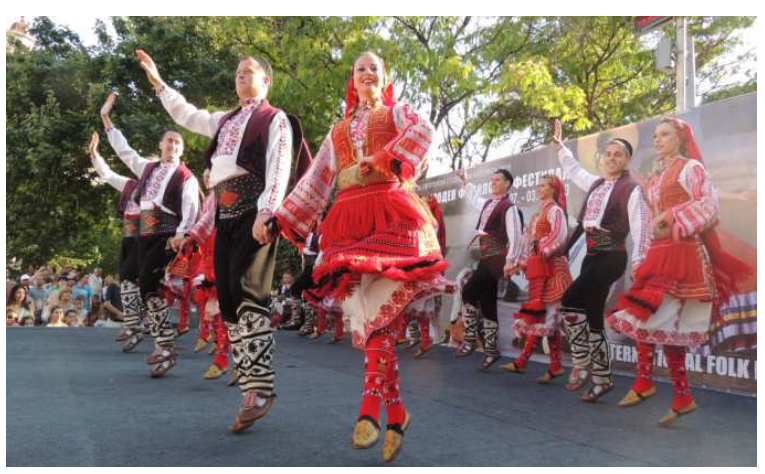

Figure №̄ 1 a. 


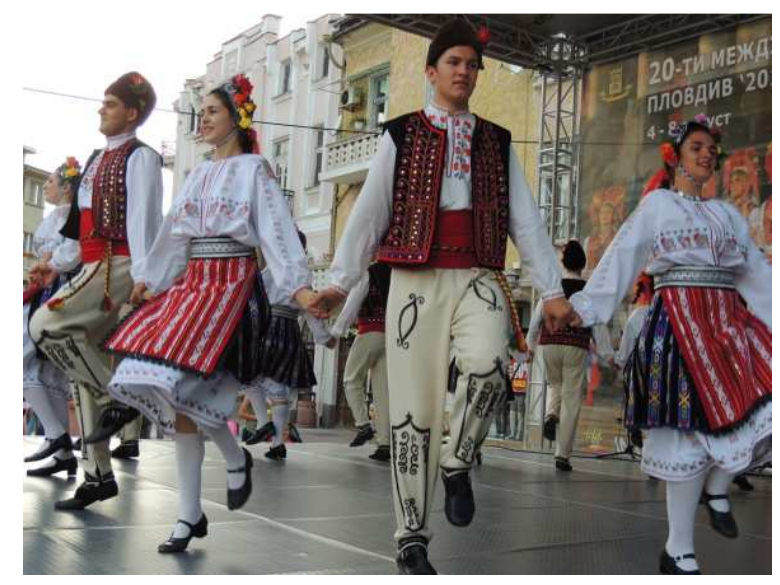

Figure № 1 b.

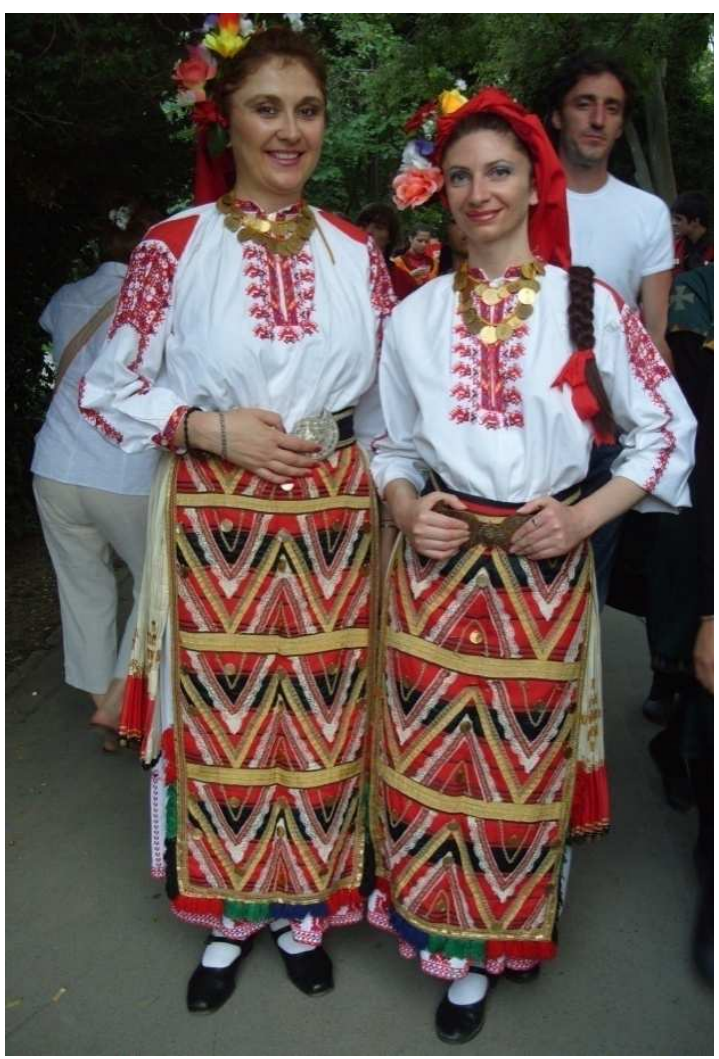

Figure № 1 c.

Figure № 1 a, b, c. Costumes from diverse regions of Bulgaria.

Of their heartfelt effort to adorn everything around them, speaks even the kneading of inventively decorated ritual breads. Also indicative are the impressive depictions of beautiful people in the lyrics of folk songs. The music, which the people create and which accompanies them in joy, hardships, work, celebration, i.e. which has turned into an inseparable element of their everyday life, also decorates, provides happiness and relief in their days. The people have created beautiful and touching songs for all kinds of possible occasions. They have created also temperamental instrumental music, on which to dance and celebrate, as wholeheartedly, as they work (Figure № 2). Actually, some celebration are organized so inventively that they can compliment work. So the art is the other passion of the Bulgarian.

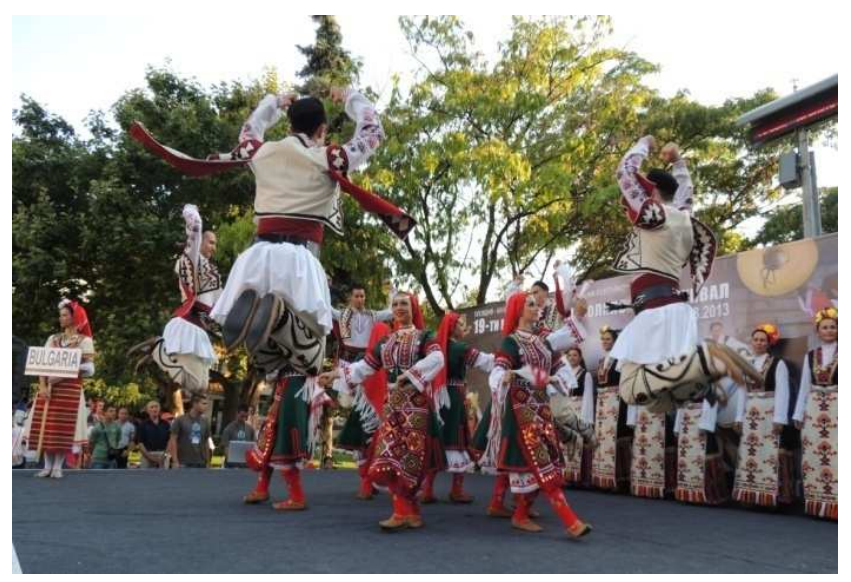

Figure № 2. Bulgarian folk dance.

Their religious feeling is a mixture of fatalism, faith in the predestination of each event, a certain adoration for the natural elements, on which their everyday life depends, the personification of these elements, faith in God. This faith does not prevent them from keeping many of their pagan traditions, as well, which, with the conversion to Eastern Orthodox Christianity, the people have carried over to their Christian traditions. Despite all, they do not rely on the mercy of the elements, nor on a fortunate destiny, neither so much in God. They rely on their two hands, on hard labor from the early morning to late in the night. Their work makes them less dependent on outside forces, work maintains their health and spirit, work makes them also happy. So it is no wonder that, despite the hard life, they show optimism and vigor.

\subsubsection{Circumstances, Related to the Folk Song "A Bright Sun has Risen"}

The Bulgarian folk song "A Bright Sun has Risen" is performed during the spring holiday Lazarus Saturday (Lazarovden), when the Christian world celebrates the raising of Lazarus. On this day, according to tradition, young girls, beautifully dressed in national costumes, with hair, adorned with flowers, gather and visit all houses, sing, dance and wish the owners health, happiness, prosperity of the family and bountiful year. The owners give the girls eggs and small sweets. Separate songs have been created for the master of the house, the mistress, the young bride, the maiden, the lad. So, the day turns into a celebration of youth, beauty, vitality, hope for abundance, the waking of nature for new life. The song "A Bright Sun has Risen" is sung in a home, where there is a maiden. In this song, an admiration for the beauty and unvarnished grace of the Bulgarian maiden is expressed.

\subsubsection{Analysis of the Bulgarian Folk Song "A Bright Sun has Risen"}

The Bulgarian folk song "A Bright Sun has Risen" has a simple strophic form. In its adaptation for choir version, an instrumental introduction has been added at the beginning of 
the song, and between the separate verses - instrumental interludes, which in emotional regard are similar to the verses. The song has an irregular meter $-{ }_{8}^{7}$, with a three beat group at the end (can be presented as ${ }_{8}^{2}+{ }_{8}^{2}+{ }_{8}^{3}$ ). In this meter, the most popular Bulgarian folk dance, "Rachenitsa", is performed. The dance is characterized by vitality, energy and fervor, in most cases it is performed in a quick tempo. The character of the melody in the song is as joyful and playful, as it is tender and gracious. The poetic beauty of the lyrics is impressive. It shows for a masterful usage of the language, in order to express much in only six lines; creativity of the comparisons; ability to observe; brimming vitality; heartwarming elegance of the description; respect for the beautiful, manifested in the lyrics, when the stepping of the young maiden Neda on the yard is likened to a the rising of the sun:

A bright sun has risen

On the even yard of Neda's family.

No, it was not a sun,

But it was Neda herself

With a waist, slender as a poplar,

With blond hair, like a fairy.

(Изгреяло ясно слънце

у Недини равни двори.

Не ми било ясно слънце,

най ми била сама Неда

с тънка снага тополова,

с руса коса самодивска).

\subsection{Analyses and Information, Related to the Piano Cycle "24 Bagatelles for Piano" by Ivan Spasov}

In order to show that the educational video can represent all kinds of emotional states, embedded in the music, I would have to review an example with a contrasting, or, at least, different character. Completely opposite in their emotional contents are the pieces from the piano cycle "24 Bagatelles for Piano" [11] by the Bulgarian composer Ivan Spasov.

\subsubsection{Psychological Characteristics of the Composer Ivan Spasov}

Ivan Spasov was an introvert, a representative of the stronger, balanced, inflexible type (which, according to the classic terminology, comes closest to a "phlegmatic"), belonged to the thinking subtype of the artistic type, possessed very low anxiety and very low levels of aggressiveness. The introversion in his musical works is related to extreme laconism, but meaningfulness of the musical language, relevance of each detail, complete lack of everything redundant (as his literary works are void of any unneeded words), lightweight texture, bright impact, despite the short duration of the opuses. Similar characterization can be made also of his literary works - the two autobiographical books, consisting of very short essays, but filled with meaning and strong emotional impact. Distinguished by this style are also the interviews of the composer, collected by one of his researchers [1]. In the books, a characteristic theme is shown, related to the introversion of Spasov - the theme of loneliness. It accompanied him during his whole life, but, through the years, it underwent a clearly visible development. At the beginning of his artistic path, loneliness was related to the inevitable isolation of the talented, who uses new means of expression, creates in an unconventional way, represents works with unusual sounding and, of course, is misunderstood, rejected and alone. In his later years, the betrayal of people, who he had considered friends, the loss of loved ones and the "stolen" by the numerous engagements minutes for creativity added new sounding to the loneliness now it was the seclusion of sorrow, of doubt, but also the precious moments for creativity. "But I led to a some extent an isolated life, especially in the last years, within a narrow circle, which was constantly becoming smaller in size... like a chrysalis in a cocoon, wrapped in a thin web of silk, continuing to stubbornly, and maybe aimlessly at this point, to weave new threads-bars. Light would permeate more and more rarely...“ („Но аз водех донякъде затворен живот, особено в последните години, в тесен крьг, който постоянно свиваше размерите си... като какавида в пашкул, увит в тънка паяжина от коприна, продължаваща упорито и вече може би безцелно да наплита нови нишки-решетки. Все по-рядко ще прониква светлина...") $[10$, p. 196]. Later, when suddenly, the only daughter of the composer died in a car accident, his loneliness became hopeless, obsessing and overwhelming. That, now, was the loneliness of suffering.

The categorization to the thinking subtype manifests its influence in the clear laconic language, in the logical organization of the musical and literary text, which, although is made of separate small elements (the succession of the essay in the autobiographical books is not chronological, but invokes emotions exactly with its structure, after the logic of contrast of themes and emotional states), moves the listener and the reader with its multiple aspects and richness of contrasting feelings, with the bright depiction of the images, created with only a few strokes. The logical organization, sought by the tone and verbal artist in anything and predefined by his psychological characteristic "thinking subtype", influenced even the choice of dodecaphony as a leading principle of expression in the musical works of Spasov.

The fact that he belonged to the strong, balanced, unmovable type, was reflected also on the ability of the composer to create in all kinds of conditions, even, very often, in the presence of noise. This gave him an opportunity not only for an incredible productivity, but also for extreme concentration, saturation with content of the musical and literary texture. The balance and inertia of the nervous activity contributed to the extremely concise usage of means of expression (since the powerful states of inactivity in the brain maintained the activity in specific, needed for the performance of the creative task, boundaries, holding back the spreading of activity to neighboring sectors, which would lead to expansion of the performers ensemble, saturation of the texture with new voices, verbosity in the language), for the minimum duration of the works, as well as for the certain 
conservativity, unchangeability in the creative signature. Spasov himself underlined that: "Of course, with the years it (the style - note by me - K. F.) undergoes changes, but whatever leaps it makes... the author, the creator remains the same. Some young composers consider this to be close to inflexibility” („Разбира ce, с годините той (стильт - б.м. К. Ф.) търпи изменения, но през каквито и скокове да мине... авторът, творецът си остава същият. Някои млади композитори считат това едва ли не за закостенялост") [9, p. 30]. Once having established the characteristic features of his musical language, the composer perfected, polished them slowly and steadily, but did not surrender for long any of them. Even, after the devastating tragic event, the expressive language of Spasov did not undergo significant changes.

\subsubsection{Circumstances, Related to the Piano Cycle" 24 Bagatelles for Piano" by Ivan Spasov}

After the death of the composer's daughter - Ioana, the devastated parent began searching for a so called in psychology "outside support", which would help him cope with the unbearableness of suffering. Such support for Spasov was faith, his reliance on God. The religious theme overtook his whole musical works. Since, in that period, the subcortex (emotional) brain activity was too intense, it powered with great amounts of energy the cortex sectors, related to creativity. For the tone artist, the language of music was the most inherent, most familiar. So, in the first years, after the demise of his daughter, Spasov fervently created music - "... like a drowning man to a straw, I clutched to art, seeking oblivion and salvation” (,...като удавник за сламка се вкопчих в изкуството, търсейки забрава и спасение”) $[9$, p. 56]. In that period, he created works with religious themes, with the exception of only several piano études, with which he completed a cycle of études that had been written earlier. Masterpieces like "Creation, Death and Resignation", "Songs of a Soul, Flying to Heaven", "Holy Bulgarian Liturgy", "Mass" and other were composed. In an interview, Spasov called them "altar" („олтарни“) works [1, p. 187]. About the first opuses of this period, the tone artist said that he had used composer techniques subconsciously. "My whole professionalism has worked subconsciously" („Целият ми професионализъм е работил подсъзнателно“) [1, p. 188]. Each of these works is a kind of an intuitive attempt by the composer for a catharsis through musical creativity.

The cycle of short pieces "24 Bagatelles for Piano" was created "in a single breath" - in seven days near the uncelebrated birthday of Spasov's daughter - Ioana, who remains forever 26 years old. The date was marked with a touching laconic comment in the sheet music after Bagatelle № 14 - "25. VI. 1995. Happy Birthday, Ionnie! Father“ [11, p 15]. This meaningful for the composer date represented also the emotional impulse for the creation of the pieces. The stimulus triggered an intensive process of catharsis. The memories became so detailed that preserved in them are clear signs of the so called in psychology "five stages of grief" [7], most of which had been already experienced (the piano cycle was created 4 years after the death of Ioana). The same five stages of grief are shown clearly also in the book "My Life an Attempt to Reconstruct a Scattered Mosaic" („Животът ми - опит за реконструкция на една разпиляна мозайка“) [9], written 2 years after the death of Ioana, as well as in several interviews with Spasov, taken by his researcher, A. Angelov [1]. In that sense, distinctive emotional paralels can be made between the words, shared by the composer and the piano pieces:

a) In relation to the first stage of reaction - the stage of denial. The first clash with a tragic event (as in this case - a car accident and the death of one of the closest people) is so confusing and devastating that we, not being able to grasp and understand its whole absurdity and horror, deny it. Years after the personal tragedy, we find signs of this initial stage in Bagatelle № 14 (Bravuro), in the comment to which Spasov congratulates his daughter for her birthday, as well as in the shared in the book: "She does not know that she has died... Without knowing, perhaps, without suspecting that something has happened, that now is not like before" („Тя не знае, че е умряла... Без може би да знае, без да подозира, че нещо се е случило, че сега не е както преди“) [9, p. 38];

b) In relation to the second stage of reaction - the stage of anger. The incursion of the inconvertible change in our lives urges us to rage furiously against it, against that, which has caused it, against our faith, which has presented it, against the powers, which did not prevent it. From the analysis of the means of expression in Bagatelle № 1 (Lento e ad libitum), it becomes clear that the balanced, calm, low-anxiety and unaggressive composer in this piece lets his own, specific for his character, outburst of anger. With the means of language, this has been expressed most clearly in the words: "All my life I will ask: is there destiny and if there is, why is it unfair? ... And I will ask, scream, until only a single word is left in my vocabulary: "WHY?" („Цял живот ще питам: има ли предопределение и ако има, защо не е справедливо?...И аз ще питам, ще крещя, докато в речника ми остане една-единствена дума - ЗАЩО?“) [9, p. 125];

c) In the sense of the third stage - the stage of bargaining. The initial anger has settled, but, then, a person feels they wish to secure more (at least a little) time, to postpone the coming of the inevitable fact, or, as it is in this case, when the event has already taken place, that he wishes he would have spent more time in the past, to dedicate to his daughter. This is clearly perceived in Bagatelle № 13 (Grazioso ma malincolico), as well as in many other miniatures from the cycle, in which Spasov paints the image of Ioana, as if trying to hold on to it for a longer time, to not lose the cherished sight of her, remembering her sometimes as a little girl, who is playing innocently and quietly (Bagatelle № 15 - Innocente e comodo), sometimes as a beautiful girl (Bagatelle № 6 Grazioso), sometimes as a pianist - gifted and strict, practicing on the piano and rebelling against the monotony of the exercises (for example in Bagatelle № 2 - Un poco bravuro, № 8 - Con brio, № 16 Alla toccata, № 18 - Vivo). In all these pieces, the painful attempts to hold on to her for a longer time are seen; to not part with the now imaginary 
vision of her. This shows through also in: "It pains me that we did not go out together more often, it pains me to think that I could have embraced and kissed you more (I know not what a father's embrace is...)" („Мъчно ми е, че не излизахме по-често заедно, мъчно ми е, като си помисля, че можех повече да те прегръщам и целувам (аз не знам какво е това бащина прегръдка...)”) [9, p. 114];

d) Regarding the fourth stage - the stage of depression. The rage, the attempts to postpone, to bring back the old state of things, have worn out the grieving person with their hopelessness. A period of waking up to reality comes, of realization of the desperation and irreversibility of its change, the stage of depression begins. This is painfully visible in Bagatelle № 17 (Adagio funebre), as well as in the admission: "I cannot go on. My soul is full of sorrow and tears. My soul begs for a little rest, so I could cry out my tears" („Не мога да продължа. Душата ми е пълна с горести и сълзи. Душата ми се моли за малко отдих да мога сълзите си да изплача"). [9, p. 19]. After these words, the page of the book is left empty;

e) About to the last stage of reaction - the stage of acceptance. This is the attempt of a person to learn to live with what has happened. A clear expression of this period of the evolution of reaction is found in Bagatelle № 24 (Con dolore e molto tranquillo) and the words, shared in an interview: "My heart bleeds placidly, my soul weeps calmly..." („Сърцето ми кърви спокойно, душата ми спокойно плаче...") [1, p. 187];

\subsubsection{Analysis of Bagatelle № 1 and other Dramaturgically Key Pieces from the Cycle of Miniatures "24 Bagatelles for Piano"}

In the piano pieces, Spasov adheres, with small exception, to the principle of dodecaphony. As the separate essays, comprising the books, so the piano miniatures are ordered more as contrasting to one another in character. Not contradicting with this, but imperceptible at first impression is the other, emotional logic of the appearance of the specific images:

a) In Bagatelle № 14 (Bravuro), the specific event for the creation of the piano miniatures is reflected. This piece is also the logical peak of the cycle. The piece begins with complex tremolos in both hands. In bar 4, the "exercise" is suddenly interrupted by a group of sixteenths with such a broken melodic graphic and variable density that it creates an impression of chaotic movement. This succession ends with an ascending melodic line, as an insistent question. The instructed articulation - staccato, also sharply contrasting with the performed in legato rhythmically even and intonationally monotonous tremolo from the previous constructions, which have created an impression of dedicated work. This contradiction between the two types of musical texture gives basis to assume that the chaotic fragment, clashing into the monotonous exercises, is a kind of protest against them, expressed with the means of piano. After a short pause, the exercise begins anew, but now with less duration and with opposite movement in both hands, which brings in a nuance of uncertainty, hesitation. Additionally, the tremolo is interrupted in the middle by a short pause. Again, a chaotic movement is heard, ending with an interrogative ascending intonation line. It is very short now, with an overall smaller texture density (a three-voice assonance appears once, a single voice is heard the rest of the time), the pause, following it, is more continuous, and, after that, only separate, sparse assonances, whose vertical structure is similar to the tremolo, appear. All of them are interrupted by pauses, as if the image of the practicing pianist is gradually dissipating and disappears.

b) Bagetelle № 14 is framed on both sides by the pieces, in which the image of Ioana, as if made of separate memories, in each of which different characteristic traits of hers are manifested, is most clearly perceived. These bagatelles are: № $2,6,8,13,15,16,18,19$. Characteristic for them is that, while in the beginning of each piece, the "action" is more condense, with less and shorter interruptions, near the end, more and more larger pauses or more frequent indications for "breath" begin to appear, as if the fragile image is dissipating gradually, like an unreal, ethereal vision.

c) Bagatelles № 7 ("Largo") № 12 ("Religioso e rigoroso"), № 17 ("Adagio funebre"), are related to the waking up to the horrible reality, seeing the fact that the loss of his daughter is irrevocable. In these bagatelles, the clear indications of character, the slow tempos, needed to follow these instructions, the unchangeable texture density and lack of prescriptions for nuances in the dynamics, i.e. "dynamic inertia", support this assertion. In these three miniatures, the described above gradual "dematerialization", dissipating of the image is not observed. The conflict of the reality (depicted through onomatopoeia - six time repetition of an assonance, consisting of symmetrically placed small thirds and small sevenths, with a prescribed accent in the dynamic forte and vibrato pedal, invoking a clear impression for the thunder of bells) and the imaginary image of Ioana as a celestial angel (represented with a short succession in a quiet dynamic and legato in the high register, with significant lighter-weight texture and frequent pauses, which contributed to the impression of "airiness", "ethereality", of diluted atmosphere), takes place in Bagatelle № 19 („Pesante e profundo").

d) The first piece - № 1 represents the strongest expression of anger, of the raging protest against the heavy stroke of destiny, while № 24 shows resignation, lonesome proud grief.

In Bagatelle № 1, the texture is "torn" into many small fragments, separated by instructions for "breaths". The piece begins with three short successions with very fragmented melodic graphic, large melodic intervals, clearly dissonant character of the assonances and a prominent contrast of long and short note values (figure № 3). The instruction for holding the whole dissonant tone successions with the pedal, continuing also in the assonances with long note values, as well as for a vibrato pedal, which covers whole successions, additionally provides sharpness, brusqueness and tension of the sound. The last assonance is provisioned to be broken in a staccato, which adds a new type of sharpness. A similar effect 
is achieved through the sudden changes in the direction of movement and the instructions for very fast performances of the sixteenths, due to the large melodic intervals, which have to be performed in a very short time. The natural ending of a phrase is a descending melodic line. However, in this first element, and as well as several other times in the bagatelle, the last melodic line before the caesura is not only ascending, but also the interval of the leap is very broad. In the initial fragment, each of the comprising motives ends with a great leap, which gives angry interrogative intonations of the successions, while the three time appearance of ascending leaps (at the end of each motif) creates an impression of insistence of the question. The whole sharpness of the expression, despite the prescribed moderate dynamic, speaks of strong emotional coloring of the fragment. Maybe exactly in the contrast of the dynamic with the rest of the means of expression, the temperament and low aggressiveness of the author find a manifestation.

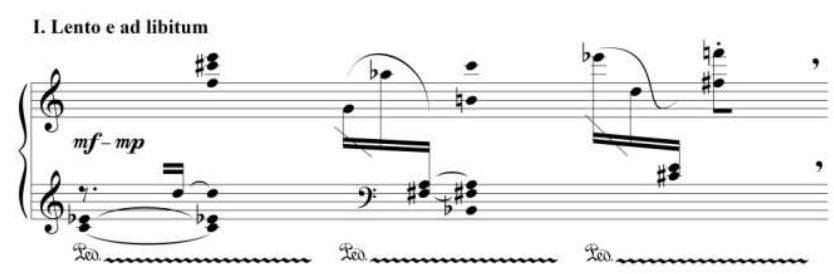

Figure № 3. I. Spasov - Bagatelle № 1 from the cycle "24 Bagatelles for Piano", first fragment.

After a mark for "breath", a succession with a very different organization is heard - long, held, according to the will of the performer, tones, standing at very short harmonic intervals from each other (figure № 4). The fragment ends with an assonance in the lower register, which includes in its contents sharply dissonating one from another tones. In this succession, there is no inscription for the usage of pedal, which results in dryness of the sound. This element is separated from the next not only by a "breath", but also by an indication for fermata, over which a clearly defined instruction for continuous duration is written (it can be seen in the figure № 5). The continuous silence creates an association with that autobiographical book [9], which was written after the death of Ioana and in which often, after the

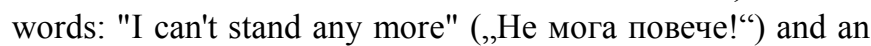
ellipsis, spanning two lines, the page is left empty until the end, while the exposition renews on the next page or even farther on [for example 9, p. 192 - 194]. The quotation, with which the next fragment in the book begins, is also eloquent: "They say - time heals. "Say?!" („Казват - лекувало времето. "Казват?!“) [9, p. 194]

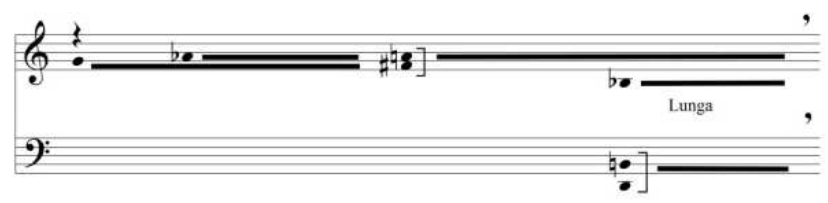

Figure № 4. I. Spasov - Bagatelle № 1 from the cycle "24 Bagatelles for Piano", second fragment.
Two groups of four repetitions in staccato, each of the same tone, follow (figure № 5). Since, in its texture organization, this fragment is similar to the culmination, it can be assumed that it, in a certain sense, is its precursor. Even from this moment until the culmination of the piece with one brief exception, the texture is from a single voice. The accompaniment has already abandoned the soloing voice, which is repeating $\operatorname{cis}^{2}$ in a tense staccato, but quietly still.

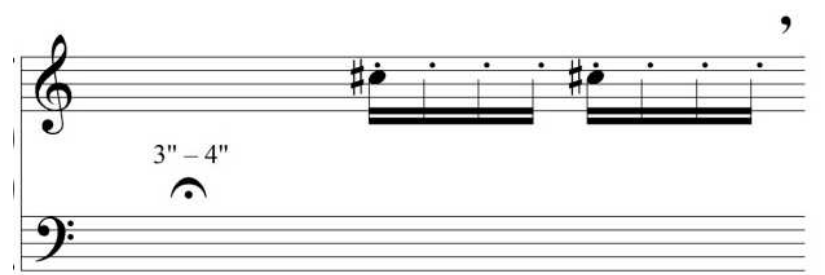

Figure № 5. I. Spasov - Bagatelle № 1 from the cycle "24 Bagatelles for Piano", third fragment.

After a new "breath", a succession with a heavily indented melodic line is heard (figure № 6). This, in a combination with the coupling of the tones in pairs, in which the second with the third tone and the fourth with the first from the next group of sixteenths are performed, while the second tone of each pair is broken in a staccato, gives the movement a feeling of anxiety, chaoticness. The inquiring ascending melodic interval appears also at the end of this fragment.

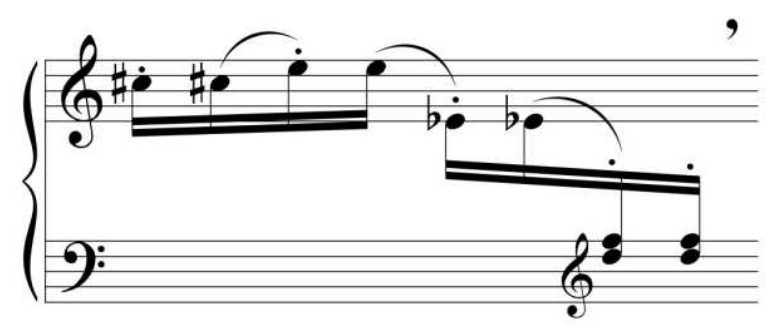

Figure № 6. I. Spasov - Bagatelle № 1 from the cycle "24 Bagatelles for Piano", fourth fragment.

A short "breath" separates this fragment from the culmination. In the peak fragment (figure № 7), the dry and sharp timbre of the high register of the piano in forte and staccato heightens immensely the tension. The supporting voices are not present. The solo (a four times repetition of the tone ges $^{3}$ ) soars lonesome, it is a scream of anger and pain, a lonesome scream, directed at no one. This is followed by a continuous interruption, marked by a "breath" and a fermata.

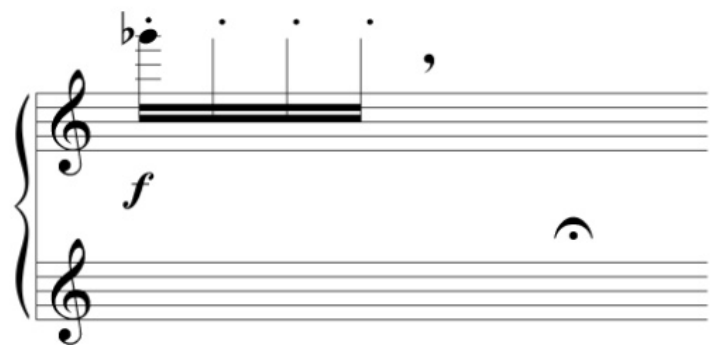

Figure № 7. I. Spasov - Bagatelle № 1 from the cycle "24 Bagatelles for Piano", fifth fragment - culmination. 
As the culmination moment, so the folloing fragments up to the end of the bagatelle are very short, often of four tones each. A sudden drop from the high to the middle register, a decrease in the dynamics and a momentary appearance of a two-voice, but again sixteenths in staccato, which maintain the tension, despite the prescribed fading, characterize the next construction (figure № 8).

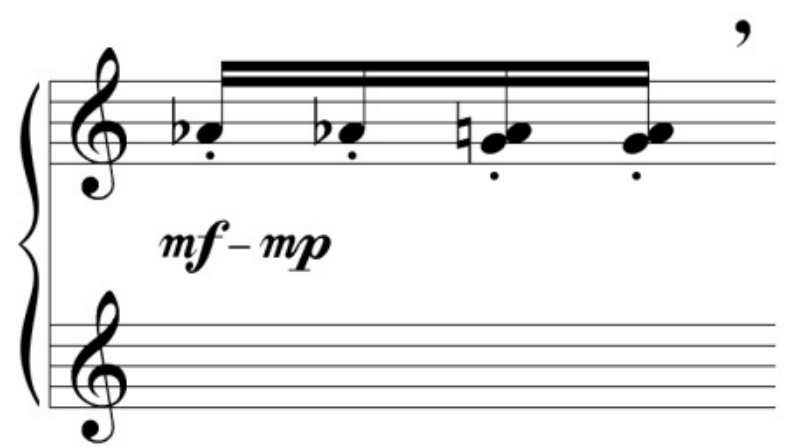

Figure № 8. I. Spasov - Bagatelle № 1 from the cycle "24 Bagatelles for Piano", sixth fragment.

At the end of the next element (figure № 9), a polyphony appears, but, after a successive descending movement, which is given a character of a quick fall by the inscription for a quick performance. Still, the last melodic interval is ascending.

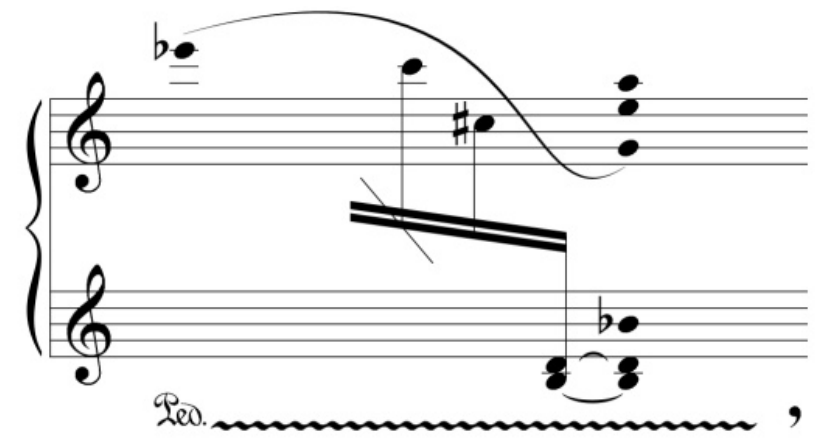

Figure № 9. I. Spasov - Bagatelle № 1 from the cycle "24 Bagatelles for Piano", seventh fragment.

The eighth fragment (figure № 10) repeats the culmination, but with a semitone lower. Again, a continuous, painful silence appears, also marked with a "breath" and a fermata. The last, ninth fragment (figure № 10) consists only of two tones in the low register, held continuously.

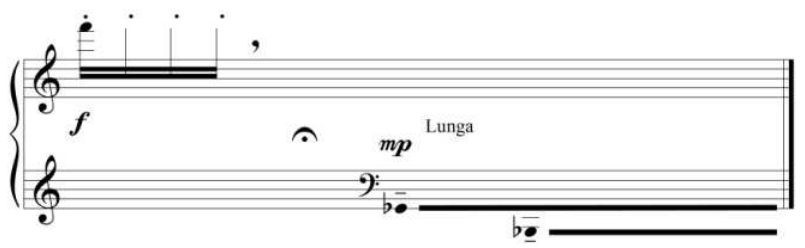

Figure № 10. I. Spasov - Bagatelle № 1 from the cycle "24 Bagatelles for Piano", eighth and ninth fragments.

The bright dynamic amplitudes, articulation and register contrasts, the sectioned by very frequent breaths exposition, the long fermati, the repeating ascending inquiring intonations at the ends of motives, all of this unambiguously expresses anger and pain.

\section{Results of the Study - Scenarios for Animation Videos}

The characteristic traits of the national psychology of the Bulgarians, which I commented above, are presented in the scenario for the Bulgarian folk song "A Bright Sun has Risen" in the following way: Neda is depicted, while she is working - going with the pails for water, or while having fun - dancing rachenitsa in front of the well, or showing tenderness - extending a hand towards a butterfly, which quickly and trustingly lands on her hand. The yard looks carefully, trimly and invitingly ordered, the well is decorated with lavish flowering bushes, Neda's pails are shining. For the fabrics of the national costume, samples have been taken from authentic, hand-crafted textiles from the same region (Northeast Bulgaria), where the folk song itself was been recorded. The elements and color combinations of the characteristic costumes from that region have been kept.

The atmosphere of the celebration Lazarus Saturday is represented through:

- The dance of Neda - rachenitsa, which she dances upright, with light, quick movements;

- The spring, whose freshness and colorfulness can be seen all over the video - in the backgrounds of the interludes (the blue sky with small fluffy white clouds, waterfalls, a stream, whose rocks are covered with bright green moss), in the verses - through the flowers, which decorated the yard, and the spectacularly woven wreath on the head of Neda, through the lavish greenness, through the beautiful butterfly "European Peacock" (widely spread in Bulgaria), which lands on the hand of Neda, through the different butterflies, characteristic for our geographic latitudes, appearing in the interludes, in order to measure with their nimble wings the meter of the rachenitsa.

- According to tradition in Northeast Bulgaria, the "lazarus girls" sing the song "A Bright Sun has Risen" in a house, where a maiden lives. For that reason, the maiden youth and beauty is one of the most important things that have to be depicted in the video to this song, while also, in connection with Lazarus Saturday - the day of young maidens. The beauty of the protagonist of the video story, Neda, is shown, at the first place, underlining the details, portrayed with beautiful comparisons in the lyrics of the song. The "waist slender as a poplar" has been exaggerated somewhat, as the maiden has been sculpted even thinner, compared to the usual proportions. The eye-catching decoration - "pafti" beltbuckle - which is an element of the national costume from North-Eastern Bulgaria, from where the song is, also underlines the gracious waist. While dancing a rachenitsa, Neda holds her hands on her hips. This pose, in its turn, contributes for her slender appearance. The "blond hair, like a fairy" is showing under the "zabradka" (a head scarf), also 
characteristic for the folklore region. The bright yellow head scarf frames the beautiful face of Neda, while the wreath of spring flowers, which she has placed over the "zabradka", enhances the impression of youth, beauty and freshness. When the butterfly trustfully lands on her hand, Neda looks at her tenderly.

The structure of the song is presented through a juxtaposition of:

a) The beautifully arranged yard of the house of Neda, with many flowers, with a path, made of hewn stones, to the covered in blooming bushes well, which is the background for the story in the verses. The action on the foreground is shown in progress, according to the specific lyrics of the verse, but all the time the background is the yard;

b) The butterfly, perched on a flower, its wings measuring the metric groups - in the instrumental interludes. The flowers, atop which the butterfly stands, are different for each new interlude; the background is also different, changing, according to the saturation of the sound (dynamic) of the interlude;

c) The butterfly, perched on a flower, on a black background - for the instrumental introduction.

\subsection{A Scenario for a Video to the Bulgarian Folk Song "A Bright Sun has Risen"}

Instrumental introduction - a butterfly, perched on a flower, on a black background, with wings, measuring the groups of the irregular meter ${ }_{8}^{7}$.

First verse - over a richly decorated with blooming flowers yard, a sun shines. In front of the sun, the translucent silhouette of a girl with a carrying pole on the shoulders appears. In this silhouette, instead of the shining sun disc, the elements of the yard become visible, as if the silhouette withstands and overpowers the sunlight. While going away from the camera in the direction of the sun, the silhouette gradually increases in opacity and color, turning into the image of a young girl. The maiden reaches the well, around which bushes bloom, and with gracious movements sets down the carrying pole with the pails.

Second verse - in front of the well, Neda dances a rachenitsa.

Third verse - the butterfly flies in front of Neda's face, who gently reaches a hand forward. The butterfly lands on Neda's hand.

Interludes - different butterflies, perched on different flowers and different background, measuring the two- and three-beat groups of the characteristic for the rachenitsa irregular meter. The colorfulness of each interlude - to what extent the used colors are bright - depends on the dynamics, with which the specific succession is performed, i.e. for the quieter sounding interludes, more dulled colors are used.

\subsection{A Scenario for a Video to Bagatelle № 1 from the Piano Cycle "24 Bagatelles for Piano" by Ivan Spasov}

Through this scenario, the anger, the maddening voidness, the self-torture, the self-destructive impulses, experienced by the composer in the phase of anger, have to be depicted. The decision for such a task requires the usage of information about the relation of the tone artist to some colors and images, for the emotional meaning, he put in them, for the impact, which the visual impressions had on him. All of this information was taken from a content analysis of the two autobiographical books [4]. Such an analysis was needed in order to isolate the random mentions of colors and images, and to single out those, which were repeated together with their emotional meaning, which the author had embedded in them, i.e. so there would be a possibility that these colors and characters were inherent to his artistic fantasy. It was found that for Spasov the green color was a symbol of the triumph of nature; the white - of purity, of innocence; the blue - of calmness, wisdom, but also coldness; the brown - of warmth; the gray - of resignation; the yellow color the tone artist related to summer, while its combination with pink - with tension, with potential energy. In the books, the image of the mountain appears, as a symbol of benevolence, of friendship, the image of the sun, which inflicts tension; sunlight is also mentioned, which brings back the unbearable reality; the night, which brings serenity, oblivion. Spasov mentions several times roots-secrets. In his books he underlines that "the subject, as well as the goal of art is the human being" (,и предмет, и цел на изкуството е човекът”) [9, p. 31], "And the goal of art is namely man, the individual person" („А целта на изкуството е именно човекът, отделният човек") [9, p. 65]. This gives basis to assume that the human being is the main character also in the music of Spasov. Taking under consideration the presence of these images and colors and the embedded in them meaning, I wrote the scenario for a video to Bagatelle № 1 .

On the background of a sky in yellow, pink and beige, an old, burnt tree stump is seen with marks from cut off low branches. The camera zooms in, the stump reaches up with two of its roots, like hands, clutches them into a fist and wearily settles them back down.

Green leaves are falling, which, on their way down gradually change their color to brown and wither away. Once reaching the ground, they, static and dry, disintegrate and disappear.

On a smooth icy surface, spread to the horizon, one by one four ice drops (in synchrony with the first four repetitions of the tone $\mathrm{c}^{2}$ in the piano piece) fall, each of them, when touching the ice, breaks into sharp particles.

A beautiful and absurdly fresh flower blooms on the ice. One by one the four leaves of the blossom are shed upon the frosted earth and freeze.

Through the branches of an withered tree, the sun beams pierce into the eyes of the observer.

Culmination. Background with the setting sun. Close view of a figure, reminiscent of the image of Ivan Spasov, with the everyday outfit, with which we, all of his colleagues, remember him - the checkered shirt in white and red and jeans. The hands are stretched out to the sides, so they cover the line of the horizon. The head is located in front of the sunset, which creates the impression of a halo. The hands rise 
and, in a gesture of dismay, grasp the head, while the whole figure shivers.

A slender, gracious sapling on a smooth field, painfully bends under the relentless gusts of the wind.

Left with no blossom, the stem of the flower slowly shrugs and freezes, like the scattered around leaves of the blossom have frozen, too. The stem and the blossom leaves are covered by icy crystals, which glimmer as cold blue sparks.

The tree stump turns over and helplessly exposes its roots, which remain sticking out like stretched up hands.

Finale. The figure of Spasov, now hunched over, with back turned at the camera, slowly walks away through the forest of black withered trees towards the sunset. The screen fades to black.

\section{Conclusions}

1. Because:

a) The images of the butterflies are associated with freedom, beauty, grace, vitality;

b) The atmosphere of tightly and nicely ordered yard creates a feeling of comfort, security, benevolence, care, as if the observer is welcomed in;

c) The festive clothes of Neda create a feeling of something extraordinary, unusual, important and exciting;

d) Neda's dance is contagious with its joyfulness;

e) The blossoming from all sides flowers and the abundant greenness invoke happiness;

it can be stated that the emotional impact of the video story to the Bulgarian folk song "A Bright Sun has Risen" has been achieved.

2. Because:

a) The tree stump - cut-off tree - is associated with the stolen opportunities for development, with a lack of perspective, with a broken life;

b) The hands clutch into a fist are an expression of anger, of a threat;

c) Destruction in various specific forms appears so often within the short video that a feeling of compulsiveness is invoked;

d) The gesture of grasping the lowered head with both hands and the shivering of the body in the culmination is a clear expression of devastation;

e) The figure, moving away from the camera and growing smaller, hunched under the burden of his despair and pain, walking through the forest of withered trees, which are stretching up their naked black branches at the end of the video, perfects the oppressive character of the video story;

it can be concluded that the emotional palette of Bagatelle № 1 from the cycle "24 Bagatelles for Piano" by Ivan Spasov has been portrayed authentically.

\section{References}

[1] Angelov, A. Ivan Spasov - 60 Steps Towards the Temple. Plovdiv, 1994

[2] Blinova, M. Musical Creativity and the Regularities of Higher Nervous Activity. Leningard, 1974

[3] Fileva, K. "24 Bagatelles for Piano", Ivan Spasov - One of the Attempts of the Composer to Achieve a Catharsis through Musical Creativity. Materials from the international scientific conference "The Musical Avangard" Perm. 2012

[4] Fileva, K. Colors and Images in "24 Bagatelles for Piano" by Ivan Spasov. Newspaper: "Musikalni Horizonti", issue 7/2000

[5] Fileva, K. Feelings and Images - video on Bagatelle № 24 from "24 Bagatelles for Piano" by Ivan Spasov

[6] Fileva, K. A Psychological View on the Personality and Work of Ivan Spasov. In Press

[7] Kubler-Ross, E. On Death \& Dying. (Simon \& Schuster/Touchstone), 1969

[8] Petkanov, K. Characteristic Features of the Bulgarian. Newspaper: Modern Geography of Culture. Native and Foreign. Coll. Albena Vacheva. Varna, Electronic Publishing House LiterNet, 2006.

[9] Spasov, I. My Life - an Attempt to Reconstruct a Scattered Mosaic. Plovdiv, 1993

[10] Spasov, I. Sky Blue Morning, Noon and Path after Noon. Sofia, 1989

[11] Spasov, I. 24 Bagatelles for Piano (Note score). Plovdiv, 1995. 